\author{
Andrzej BogusŁawski \\ Uniwersytet Warszawski \\ Katedra Lingwistyki Formalnej
}

\title{
Kolejna glosa do rozważań wokół pojęcia wiedzy i jej stosunku do niealetycznych stanów mentalnych
}

Słowa klucze: wie, że; przekonanie

Keywords: knows that; belief

Od czasu powstania platońskiego Menona po dziś dzień dominująca pozycję w teoretyzowaniu na temat 'wiedzy', w szczególności zaś na temat powszechnie uznawanego za podstawowe, a w każdym razie za niezwykle doniosłe, jeżeli nie zgoła najdonioślejsze, pojęcia 'wie, że', zajmuje pogląd, zgodnie z którym jest to pojęcie złożone. Nad wątpliwościami dotyczącymi tej złożoności, a nawet nad pewnością niektórych myślicieli, że o żadnym złożeniu semantycznym nie należy tu mówić, masowo przechodzono, i przechodzi się, do porządku dziennego. Wypowiedź Konfucjusza z połowy ostatniego tysiąclecia przed Chr., w której mistrz za główny fragment czy aspekt wiedzy uznał wiedzę o samej wiedzy ujętą w (z grubsza) następujących słowach: ,wiedzieć to wiedzieć, a nie wiedzieć to nie wiedzieć” oraz ,jest fałszywą wiedzą mówić, że się wie to, czego się nie wie, i że się nie wie tego, co się wie" miała oddźwięk raczej słaby. A przecież w oczywisty sposób była to deklaracja na rzecz niedefiniowalności ‘wiedzy'. I była to deklaracja znakomicie sformułowana, bo oparta na odesłaniu do właściwej pary, tzn. alternatywy, kontradyktorycznej. 
Zgodnie z niemal uświęconym zwyczajem wciąż powtarza się objaśnienie, w myśl którego zjawisko 'wie, że' jest niejako „nadbudowane” nad pewnym zjawiskiem prostszym. Jest to nawet tendencja do pewnego stopnia zrozumiała, ponieważ wiedzę uważa się za największy skarb. Otóż asocjacja złożoności takiego skarbu jest przepotężna, zwłaszcza w odczuciach ludzi, którzy nie bez przyczyny (choć niesłusznie) mają siebie, ze swą dodatkowa wiedzą, mianowicie wiedzą werbalna, za pępek wszechświata.

Suponowane prostsze zjawisko bywa nazywane różnie. Zapewne przeważa odwoływanie się do ang. belief, pol. przekonania, ale wykorzystuje się też hasła sqd, pewność (ang. sure; por. Leibniza definicja scire w postaci res cognoscere per probationes certas), uznanie (jak u Ajdukiewicza, Jadackiego), akceptacja (ang. acceptance, jak u Chisholma); stosuje się też inne terminy.

Dalsze atrybuty, mające dostarczyć koniecznej differentia specifica wiedzy w jej relacji do takich stanów mentalnych, które nie mogą pretendować do nazwy wie, że, obejmują 'prawdziwość' owego ,przekonania” i jego 'uzasadnienie'. Zbiorczo stanowisko to jest we współczesnym piśmiennictwie nazywane standardowo skrótem JTB, od ang. justified true belief.

Stanowisko takie bywa najczęściej prezentowane jako adekwatne $w$ sposób bezdyskusyjny, w sposób oczywisty. Tak np. Woleński (2005: 360) wspomina wprawdzie o całej sprawie niedefiniowalności 'wie, że', odnosząc jej głoszenie do moich wypowiedzi, ale kwituje całą sprawę krótkim, pozbawionym jakichkolwiek dodatkowych komentarzy, stwierdzeniem, że tą propozycją nie będzie się (w swym bardzo obszernym dziele) zajmować. Omija przy tym, zarówno w tekście głównym, jak i w bibliografii, takie dobrze znane z tradycji wypowiedzi opowiadające się za pierwotnością i niedefiniowalnością 'wiedzy', jak te z pism Fichtego, Cooka Wilsona, Pricharda, Hintikki, Lenzena, Wierzbickiej, Williamsona (by ograniczyć się do kilku przykładów innych niż wypowiedzi Konfucjusza). Z odwołaniem do autorytetu Woleńskiego, równie krótko i apodyktycznie, „przekonaniową” wizję wiedzy kwalifikuje jako niepodważalny i niekontrowersyjny, elementarny punkt wyjścia we wszelkich aprobowanych przez siebie rozważaniach o stanach mentalnych Ciecierski (2013: 172, przypis); chodzi tu o jego rozważania przeciwstawiane temu, co autor znajduje w pewnych pracach polskich, m.in., w rozprawie Danielewiczowej (2002) i w jednym moim artykule (autor mówi też ogólnie o ,pewnych lingwistach”, nie precyzując jednak bliżej ich listy). 
Warto w tym związku wspomnieć na samym początku, iż istnieje prosty test wewnętrznojęzykowy, którego zastosowanie całkiem niedwuznacznie $i$ konkluzywnie podważa ideę jednostronnej inkluzji 'wie, że' w 'jest przekonany, że' (lub w jakimkolwiek innym funktorze o podobnym charakterze). Test ten polega na wprowadzeniu 'wie, że' na pozycję prawostronną, a 'jest przekonany, że’ na pozycję lewostronną konkatenacji opartej na nadrzędnym (nadrzędnym w sensie ajdukiewiczowskim) „spójniku” mianowicie. Wynik, jaki otrzymujemy, jest ewidentnie dewiacyjny; por. *Obama jest przekonany, że Putin dokonat aneksji Krymu, mianowicie wie, że do tego doszło. Rzecz w tym, iż zgodnie z semantyką wyrażenia mianowicie po prawej stronie tego funktora podaje się warunek wystarczający, ale nie konieczny, tego, co jest zawarte w członie lewostronnym (por. On mieszka $w$ Anglii, mianowicie mieszka $w$ Londynie.). Otóż wedle standardowej teorii wiedzy atrybut 'wie, że' stanowi właśnie warunek wystarczający stanu 'jest przekonany, że' (bez równoważności tych dwóch pojęć). Wskazany test pokazuje jednak, że taka relacja między 'wie, że' a 'jest przekonany, że' nie zachodzi. Z tym inkryminowana teoria pozostaje w oczywistej sprzeczności. Zmusza to do jej odrzucenia. Skądinąd omówiony tu rozstrzygający test, trzeba przyznać, nie jest nigdzie stosowany (abstrahuję od własnych wypowiedzi); ale jest to jedyna jego wada.

Istnieje naturalnie, poza przedstawionym testem, rozgałęziona argumentacja na rzecz pierwotności pojęcia 'wie, że'. Sprawie tej poświęciłem w swych publikacjach wiele miejsca. Nie będę tu rekapitulował w sposób szczegółowy całokształtu swoich obserwacji.

Korzystne może natomiast być podanie werbalnego (nie wyczerpującego) „katalogu” argumentów na rzecz (absolutnej) pierwotności 'wie, że'.

Katalog ten obejmuje, po pierwsze, argumenty, które można nazwać kardynalnymi pozytywnymi; po drugie, argumenty, które można nazwać kardynalnymi negatywnymi (tzn. obalającymi definiowalność 'wie, że'); wreszcie argumenty uzupetniajace.

Oto ten katalog:

\section{A. Argumenty kardynalne pozytywne}

- dowód niedefiniowalności 'wie, że' podany przeze mnie w książce z r. 2007

- charakterystyka 'wie, że' w: Bogusławski 1998 
- a. z zakresu referencji: niemetaforyczność wiedzy zwierząt

- a. z najwyższej frekwencji (wśród "wyrażeń epistemicznych")

- a. z powszechnej nieproblematyczności sensu 'wie, że'

- a. z iteracyjnej dewiacyjności 'wie, że' w rekurencyjnym przekładzie 'wie, że' na 'istnieje' i vice versa

- a. z powszechności potencjalnego prefiksu 'ktoś wie ...' w bazie języka (dotyka tego problem fregowskiej "powagi", a także równość praktycz$n y c h$ konsekwencji wypowiedzeń o kształcie $p$ i o kształcie wiem, że p)

- a. z relacji 'wie' do 'fałszu', 'prawdy' (por. Bogusławski 2007a)

- a. z układu responsów: 'tak', 'nie', 'nie wiem' (obserwacja O.A. Wojtasiewicza, później M. Danielewiczowej)

- a. z potrzeb interpretacyjnych alternatywy i "konwencji (T) Tarskiego"

- a. z potrzeb interpretacyjnych "struktury tematyczno-rematycznej"

- a. z niemożliwości istnienia zdania określonego jako 'prawdziwe' (w sensie 'głoszące prawdę'), co do którego literalnie żaden podmiot epistemiczny nie wie, czy prezentuje ono prawdę (o tym, kogo / czego to zdanie dotyczy), czy też prezentuje jej odwrotność.

\section{B. Argumenty kardynalne negatywne (obalające JTB)}

- a. Gettiera (Gettier 1963; Bogusławski 2002)

- a. z relacji w stosownych układach z 'mianowicie' (por. wyżej)

- a. z braku inferencji do 'sądzi' od nieakceptacji a wie, że ... (Bogusławski 1994; Bogusławski 2007)

- a. z nieskuteczności odwołania do hipotezy skalarności "jest przekonany $<$ wie" (por. stosowne fragmenty obecnego tekstu w dalszych akapitach)

- a. z konfliktu JTB ze zdaniami o Bogu (typu Bóg mi świadkiem; nie ma sensu mówić o ,przekonaniach” Boga).

\section{Argumenty uzupelniające}

- a. z defaultowego braku zwrotu 'dlaczego wie'

- a. z niekaralności wiedzy

- a. z braku "double-barreledness" 'wie, że' w zdaniach warunkowych (Geach 1963; Bogusławski 2007)

- a. z różnicy między 'let know' a 'prohibit to accept $p$ '

- a. z funkcjonowania 'też' i jego odpowiedników w innych językach (Bogusławski 1986, 2007) 
- a. z pewnych aspektów zdań wartościujących estetycznie (Bogusławski 2007)

- a. z produktywności semantyczno-eksplanacyjnej 'wie, że' (np. w analizie 'ten' i pod., tzn. demonstrativów, por. Bogusławski 1991; w analizie 'zdradzić, że', por. Bogusławski 1988, 2005a).

W swej kolejnej glosie poświęconej miejscu funktora 'wie, że' w systemie wyrażeń epistemicznych odniosę się w szczególności do wywodów T. Ciecierskiego w jego pracy z r. 2013. Są one bardzo charakterystyczne dla pewnego szeroko reprezentowanego kierunku myślenia o sprawach tu poruszonych, a zarazem dotykają bezpośrednio i eksplicytnie poglądów przeciwstawnych, m.in. rozwijanych, jak wspominałem, przez Danielewiczową w jej różnych pracach, przede wszystkim w jej obszernej książce z r. 2002 podającej kompletny obraz stanowych czasowników epistemicznych w języku polskim, a także poglądów rozwijanych przeze mnie w szeregu przyczynków. W obecnym kontekście przyjrzenie się różnym opiniom i przedłożeniom autora (traktującym m.in. tylko o jednej z moich wypowiedzi) może być pożyteczne.

Autor rozważa krytycznie niektóre argumenty na rzecz niezależności 'wie, że' od 'jest przekonany, że', 'sądzi, że' lub podobnych funktorów.

Na początek rozpatrzę jego kontrargument mający uchylać tezę Abelsona (1968) o pragmatycznej niestosowności dodania ' $a$ wie, że $p$ ' do ' $a$ jest przekonany, że $p$ '; teza ta była zresztą ograniczona przez krytykowanego autora do form 1 osoby lp.

Ciecierski mówi uogólniająco o zdaniach z dowolnym $a$. Jego kontrargument polega na próbie osłabienia wymowy wchodzącego w grę zgrzytu koniunkcyjnego (* Stefan wie, że Kant urodzit się w roku 1724 i jest przekonany, że urodził się w roku 1724.; mój przykład): zdaniem autora 'jest przekonany' niesie tylko implikaturę skalarnq równą 'nie jest tak, że wie', tzn. implikature „,braku wiedzy” generowaną przez sam fakt użycia takiego słabszego niż 'wie, że' elementu skalarnej alternatywy wyrażeń epistemicznych, jakim jest 'przekonanie'. Dowodzić tego, że taka właśnie sytuacja zachodzi, ma akceptowalny, zdaniem autora, ciąg ilustrowany następującym przykładem: Jestem przekonany, że Jan jest szczęśliwy. Co więcej, ja to wiem.

Kontrargument Ciecierskiego jest jednakże nieskuteczny, bo w swej interpretacji podanego przykładu autor ignoruje argumenty na rzecz nieskalarności wchodzących w grę predykatów oraz możliwość ,,autopoprawkowości” 
zawartej w jego przykładzie, która świadczyłaby właśnie o wadliwości koniunkcji 'jest przekonany' i 'wie'. Ta wadliwość staje się zresztą dostatecznie oczywista, kiedy tylko przyjrzymy się bacznie jednozdaniowym koniunkcjom typu * Wiem i jestem przekonany, że_/* Jestem przekonany $i$ wiem, że . Co się tyczy suponowanej „skalarności” prezentowanej jako “'przekonany” $<$ 'wie'», to jest ona przez autora jedynie zadeklarowana. O jej iluzoryczności powiem niżej, omawiając inne wywody autora.

Po odrzuceniu „wyjaśnienia z odwołaniem do skalarności” za jedynie właściwą należy uznać interpretację przykładów w rodzaju zdania przytoczonego przez Ciecierskiego jako realizujących we właściwym ciągu wypowiedzeń, zgodnie z przed chwilą sformułowaną sugestią, autopoprawke mówiącego. O dokonywaniu takiej autopoprawki przez mówiącego trzeba powiedzieć, że jest ona czymś całkowicie incydentalnym. Odpowiednie fakty nie mają żadnej wagi dla wywodów składniowych lub semantyczno-pragmatycznych, takich jak leżące u podstaw idei „skalarności” zastosowanej w sposób tu omawiany. Co więcej, autopoprawkowość występująca w przykładzie Ciecierskiego doskonale harmonizuje właśnie z radykalnym kontrastem zachodzącym między 'wiedzą' a 'przekonaniem'.

Drugim elementem ,antyabelsonowskim” w wywodach Ciecierskiego jest próba pokazu domniemanej sprzeczności, jaka miałaby wynikać z ewentualnego założenia ,abelsonowskiego” w postaci oznaczonej przez krytyka Abelsona nazwą (INK).

Treścią (INK) jest implikacja Kap $\Rightarrow \sim$ Bap, gdzie Kap odnosi się do 'wie, że p', a Bap - do 'jest przekonany, że p' (zapisy są rozumiane w sposób oczywisty). Proponowana przez autora dedukcja sprzeczności przebiega następująco. Mamy (VER) Kap $\Rightarrow$ p. Z (INK) i (VER) otrzymujemy Kap $\Rightarrow \mathrm{p} \wedge \sim$ Bap. Przyjmujemy dalej, że w następniku tej ostatniej implikacji podstawieniem $p$ może być $B a q$, oraz że, odpowiednio, zachodzi KaBaq. Wtedy z Kap $\Rightarrow p \wedge \sim$ Bap otrzymujemy: $\mathrm{KaBaq} \Rightarrow \mathrm{Baq} \wedge \sim \mathrm{BaBaq}$. Następnie przyjmujemy ,zasadę introspekcji” Baq $\Rightarrow$ BaBaq. Ta „zasada” prowadzi do implikacji $\mathrm{KaBaq} \Rightarrow \mathrm{BaBaq} \wedge \sim \mathrm{BaBaq}$. Ostatecznie na mocy modus ponens zastosowanego do tej implikacji otrzymujemy sprzeczność: BaBaq $\wedge \sim$ BaBaq.

Kontrargument ten jest jednak znowu nieskuteczny, bo sama ,zasada introspekcji”, tzn. zasada automatycznej iteracji czy też rekurencji $B$, jest nie do przyjęcia przy dojrzałej analizie $B$ (nawet jeżeli jest rzeczywiście 
stosowana rutynowo przez wielu epistemologów). Analiza $B$ i $B B$ pokazuje mianowicie, że $B B$ jest sprzecznościorodne; podobnie jest z wzajemnymi embeddingami wielu wyrażeń epistemicznych takich jak $B$; znanym żartem opartym na tym zjawisku jest włożone przez S. Wiecheckiego w usta jego bohatera Walerego Wątróbki powiedzenie przypuszczam, że watpię.

Zacznijmy od proponowanej przeze mnie w artykule (2005), z obszernym uzasadnieniem, reprezentacji $B$, tzn. 'believe':

- $a$ [TD] about whom I do not say that $a$ knows that $p$, about whom I do not say that $a$ knows that $\sim p$, who knows that something ${ }_{i}$ is the case such that

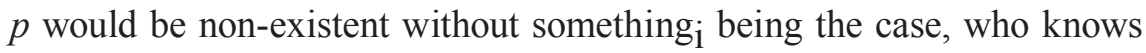
that something $\mathrm{i}_{\mathrm{i}}$ is the case such that $\sim p$ would be non-existent without something ${ }_{i}$ being the case

- $[\mathrm{R}]$ knows that i f $a$ currently says to someone $\mathrm{k}_{\mathrm{k}}$ that one of the following: $p, \sim p$, is the case, does not currently say to someone $\mathrm{k}_{\mathrm{k}}$ something (out of: $p, \sim p$ ) such that $a$ would not say it to $a$ [to him/herself], th e n $a$ would say that $p$

Co otrzymujemy jako reprezentację $B B$, czyli konstrukcji a believes that a believes that $p$, w drodze zastosowania do tego przypadku przedstawionej wyżej, najbardziej adekwatnej, reprezentacji $B$ ?

Otrzymujemy to, co opisałem w przywołanym artykule, a mianowicie charakterystykę podmiotu epistemicznego zawierającą sprzeczność. Tekst zdający sprawę ze sprzeczności tkwiącej w $B B$ brzmi:

„Here, the speaker declares in advance and in a presuppositional manner that the epistemic subject opts n e it h e $\mathrm{r}$ for his/her knowledge of the presence of his/her own possible option on account of his/her own possible choice of one of the two propositions (as the true one): $p$, not- $p, \mathrm{n}$ o $\mathrm{r}$ for his/her knowledge, in the last resort, of the absence of his/her own possible option on account of his/her own possible choice of one of the two propositions: $p$, not- $p$. The speakers next step, however, is to declare that the epistemic subject possibly opts (and knows about this option made by him/her) for the presence of his choice of one of the two propositions: $p$, not- $p$, to wit, for his choice of $p$, while at the same time combining it with his/her suspension of his/her self-appraisal as knowing that $p$, as well as of his/her self-appraisal as knowing that not-p. As a result, the epistemic subject appears to admit his/her option in favour of $p$ without, however, acknowledging his/her responsibility for his/her knowledge of the very presence of such an option on his/her part (in addition, s/he makes 
a reservation concerning a far-reaching lack of sufficient grounds for that kind of option on his/her part).

All of this contradicts a general truth concerning saying that, viz. the analytic truth that whoever says that, knows that s/he says that. The reason why that kind of contradiction does flaw a sentence patterning with the description presented above is that the option we were discussing is nothing other than such a saying. Therefore, the asterisk as used above [uwaga: $B B$ zostało opatrzone gwiazdka sygnalizująca dewiację] is fully justified. At the same time, we have thus pinpointed the specific source of the deviance."

Dodajmy, że co się tyczy konstrukcji o kształcie * a believes that a does not believe that $p$, to $\mathrm{w}$ tym odniesieniu pozostaje w mocy wszystko to, co zostało powiedziane wyżej, z wyłączeniem faktu, że fraza does not believe that ostatecznie prowadzi, w oczywisty sposób, do opcji na rzecz nie $p$.

Osobno trzeba odnotować, że już zastosowany przez Ciecierskiego embed$\operatorname{ding} B$ w $K$ jest semantycznie (nie: składniowo!) dewiacyjny. Otrzymujemy bowiem, zgodnie z przedstawioną analizą $B$, koreferencyjną rekurencję $K$ : podmiot epistemiczny miałby wiedzieć, że wie, że ewentualnie powie to a to. Harmonizuje to $\mathrm{w}$ pełni $\mathrm{z}$ łatwo intuicyjnie uchwytną dziwacznością zdań w rodzaju Wiem, że sqdzę, że on już nie przyjdzie. Jak pokazywałem w swoim (2005), całkiem inaczej przedstawia się sprawa embeddingu $K$ w $B$; i znowu jest to zgodne z pozytywnym intuicyjnym odbiorem zdań takich, jak Sadzę, $\dot{z}$ e wiem, że tę książę położyłem na najwyższej półce., Sadzę, że wiem, gdzie położytem tę ksiażke.

Kolejnym autorem, wobec którego Ciecierski broni zawierania się 'przekonania' w 'wiedzy', jest Danielewiczowa (2002). Jej obszerną argumentację na rzecz niezależności 'wiedzy' od 'przekonania' można streścić jako następującą obserwację: mamy poprawne koniunkcje negacji sądu z deklaracją wiedzy, koniunkcje typu a nie sqdzi, że p, a wie, że p, przy czym nie ma żadnych racji po temu, by interpretować takie koniunkcje jako stojące na miejscu konstrukcji 'nie tylko sądzi, lecz także wie'.

Kontrargument Ciecierskiego, podobnie jak w przypadku jego polemiki z Abelsonem, polega na podtrzymywaniu tezy o sprecyzowanej wyżej „skalarności” wiadomych predykatów i związanych z nią implikaturowych efektów pragmatycznych. Ciecierski po prostu odrzuca to, co głosi Danielewiczowa, i nalega na obowiązkowości interpretacji zdań typu nie $s q d z i$, wie jako faktycznie reprezentujących treść ' $n$ ie $t y l k o$ sqdzi, więcej: 
wie'. Ponadto twierdzi, że wskazywanie na innq lekturę nie jest niczym więcej, jak sposobem powtórzenia tezy autorki o braku 'przekonania' w 'wiedzy'. Jest to ze strony autora posunięcie metodologicznie niepoprawne: onus probandi spoczywa na tym, kto dokonuje interpolacji w stosunku do czystego brzmienia rozważanego sformułowania, a więc w tym wypadku spoczywa na autorze. Danielewiczowa zwraca uwagę na obecność koniunkcji nie $s q d z i$, wie bez tylko i wybiera „opcję zerową”, która ma oparcie w empirycznym fakcie różnicy między okurencjami bez tylko a okurencjami, w których pojawia się to wyrażenie. Ciecierski pomija ponadto milczeniem obserwację Danielewiczowej mówiącą o tym, że w zdaniach, o które jej chodzi, typowo występuje intonacja kontrastywna, która podkreśla przeciwstawienie wiadomych predykatów. Przypomnijmy, że normalnie wyrażenia sqdzi/nie sqdzi są nieakcentowane: przycisk frazowy pada z zasady na uzupełnienie propozycjonalne, inaczej niż w wypadku wie [prymarnie akcentowanego] lub mówi [alternatywnie akcentowanego i nieakcentowanego]. Natomiast w inkryminowanych wypadkach mamy kształty, które można zobrazować zapisem: nie $S A D Z I$, że pada deszcz (taka fraza przeciwstawia się jako fraza szczególna, korekcyjna, podstawowym frazom nie sadzi, że pada DESZCZ/by padat DESZCZ).

Jest rzeczą ciekawą, że autor po tym, jak zupełnie nietrafnie imputował Danielewiczowej dogmatyzm w potraktowaniu relacji między wiadomymi predykatami (jako nie ułożonymi „skalarnie”), zdał sobie jednak sprawę z potrzeby pozytywnego argumentu na rzecz swej własnej lektury skalarnościowo-implikaturowej i z niedostateczności takiej jego kontrargumentacji w stosunku do ujęcia autorki, o jakiej była wyżej mowa. Za potrzebny argument pozytywny uznał wskazanie na sytuację zachodzącą w następującym możliwym zdaniu: Miluś nie jest ptakiem, jest kondorem., gdzie 'kondor' implikuje 'ptak', a mimo to neguje się orzecznik 'ptak' (bo, według autora, zachodzi skalarność «'ptak' < 'kondor'»). Jest to argument błędny: retoryczna zabawa w sprzeczność leży w przykładzie autora jak na dłoni, podczas gdy przykładom Danielewiczowej jest właściwa zupełna neutralność konstatacyjna; o żadnej sprzeczności nie może tam być mowy. Znajduje to odbicie w następującym kontraście możliwych wypowiedzeniowych kontynuacji zdań Danielewiczowej, z jednej strony, i zdania Ciecierskiego, z drugiej. Mamy mianowicie w pierwszym wypadku całkiem sensowne uzupełnienia typu Gdyby nie byto tak, że a wie, że $\mathrm{p}$, to zapewne byłoby tak, że 
a $s q d z i, \dot{z} e$ p., podczas gdy dodanie do zdania o Milusiu potraktowanej na serio uwagi Gdyby Miluś nie byt kondorem / ptakiem z gatunku 'kondor', to zapewne byłby ptakiem. byłoby jawnym dziwactwem (dziwactwem także z punktu widzenia trafnej „koniecznościowej” interpretacji imion własnych i pojęć gatunków naturalnych, jaką podał Kripke: wyobrażalny brak przynależności Milusia do kategorii kondorów nie pozostawia żadnego miejsca na konieczna jego przynależność do kategorii ptaków).

Najbardziej jednak zasadniczym błędem Ciecierskiego jest nieuwzględnienie następującej okoliczności semantycznej: sformułowania $\mathrm{z}$ nie tylko bynajmniej nie przesądzają inkorporowania treści z lewej strony w treść z prawej strony. Często chodzi o przesądzenie pewnej hierarchii rzeczy z określonego punktu widzenia, które inkluzji, o jaką chodzi autorowi, wcale nie zakłada. Nawet więc gdyby należało interpretować koniunkcje typu nie $s q d z i$, wie przez pryzmat jakoby elidowanego nie tylko, nie oznaczałoby to, że 'sąd' jest zawarty w 'wiedzy'. Oto przykłady innych konkatenacji z nie tylko: On nie tylko nie przeciwdziałal Niemcom, on donosit do Gestapo. (donoszenie do Gestapo nie obejmuje braku przeciwdziałania Niemcom); On nie tylko styszał tę wersję wydarzeń, to on ja puścit w obieg. („on” nie musiat słyszeć tego, co się mówiło); Nie tylko ja pogłaskat, pocałowat ja (pocałunek nie pociąga za sobą pogłaskania). Relacja 'sądzenia' i 'wiedzy' egzemplifikuje taką właśnie sytuację. Jest to nawet jeden z oczywistych układów hierarchicznych, w którym zarazem żadnej implikacji „niższego” przez „wyższe” nie musi być. Co więcej, takiej implikacji tam ani nie ma, ani nawet być nie może: choćby dlatego, że „wyższy” partner w postaci wiedzy jest właściwy zwierzętom, które stanów „niższych” w postaci przekonań w ogóle nie znają (niezależnie od tego, co na ten temat mówi autor; a istotnie skłania się on, rzecz dziwna, do przypisywania zwierzętom przekonań).

Przechodzę do uwag na temat potraktowania przez Ciecierskiego jednego z moich własnych artykułów, w którym poruszałem sprawy tu omawiane; chodzi o artykuł z r. 1994 (moje inne, dość liczne, prace dotykające obecnego tematu nie stały się przedmiotem żadnych uwag autora).

Autor odnosi się krytycznie do mojego argumentu mówiącego o 'sądzeniu' jako implikującym 'niewiedzę'. Ten mój argument można streścić w sposób następujący: ,a sqqdzi, że $\mathrm{p} \rightarrow$ a nie wie, czy p; Kpa $\rightarrow$ a wie, czy $p$; ergo: $(\mathrm{Kpa} \rightarrow a$ sqdzi, że $\mathrm{p}) \rightarrow(\mathrm{Kpa} \rightarrow a$ wie, czy $p \wedge$ a nie wie, czy $p)$; 
w wyniku otrzymujemy z przypuszczenia, iż w 'wiedzy' zawiera się 'sąd', wniosek, że Kpa implikuje sprzeczność; tymczasem Kpa w oczywisty sposób nie jest sprzeczne wewnętrznie; ergo: owo przypuszczenie należy odrzucić". Krytyka tego argumentu dotyka pierwszej z przywołanych tu implikacji: autor jej nie przyjmuje. Że taka implikacja nie zachodzi, dowodnie pokazała Danielewiczowa w swej książce z r. 2002, czego autor nie odnotował (notabene swoją nietrafną supozycję zawarłem już w artykule z r. 1981, a więc trzynaście lat przed publikacją z r. 1994). Tak czy inaczej zgadzam się z tą krytyką Ciecierskiego.

Ale ponadto powtarza on również w tym odniesieniu swą tezę o ,skalarności" wiadomych predykatów i zarzuca mi w związku z tym błąd ekwiwokacji, który polegałby na tym, że biorę skalarnościowa implikature 'niewiedzy' za logiczne implicatum 'sądu'. W tej mierze, w jakiej wspomniana teza o „skalarności” zasługuje na odrzucenie, zgodnie z tym, co przedstawiłem wyżej, muszę uznać zarzut ekwiwokacji za bezprzedmiotowy. Ekwiwokacja w moim ujęciu zachodziłaby, gdyby została intersubiektywnie ustalona owa implikaturowość wiadomej inferencji 'niewiedzy'; tymczasem przyjęcie takiego statusu owej inferencji jest właśnie przedmiotem sporu. Zatem przywołanie tezy o tego rodzaju statusie omawianej inferencji jako kontrargumentu to błąd petitio principii ze strony krytyka.

Ciecierski nie ustosunkował się do całego szeregu innych argumentów na rzecz niedefiniowalności 'wie, że' prezentowanych w moich pracach z r. 1981, 1994 i szeregu późniejszych, zwłaszcza w bardzo obszernym wywodzie z roku 2007. W tym miejscu przypomnę jeszcze raz swoją analizę believe w cytowanym wyżej artykule z r. 2005. Zgodnie z obszernie argumentowaną wykładnią 'sądzi' zawartą w tym artykule i powtórzoną przed chwilą predykat ten obejmuje presupozycję przewidująca, że właściwy podmiot epistemiczny nie mówi, że wie, że $p$ i nie mówi, że wie, że $\sim p$. Otóż taka presupozycja jest bezpośrednio niekompatybilna $\mathrm{z}$ atrybutem podmiotu w postaci powiedzenia, że a wie, że $p$; jest tak właśnie, nawet jeżeli predykat 'sądzi' nie wyklucza faktu, że podmiot ostatecznie wie, że $p$ (brak takiego wykluczenia, jak przed chwilą przypomniałem, pokazała Danielewiczowa). Wystarczy to (jeżeli przyjąć wskazaną wykładnię), by uznać, że przypisanie komuś zaledwie sądzenia, że $p$, wyklucza przypisanie tej osobie, a także używającemu odpowiedniego predykatu, gotowości powiedzenia, że dana osoba wie, iż $p$. Przeciwstawność więc 'wiedzy' i ‘sądzenia', o jaką chodziło i mnie 
i Danielewiczowej, oraz brak zawierania się drugiego zjawiska w pierwszym i drugiego orzeczenia o jakimś podmiocie w pierwszym orzeczeniu pozostaje. Ciecierski nie wskazał żadnych okoliczności, które pozwalałyby podtrzymać jego wizję zawierania się 'sądu' czy też 'przekonania' w 'wiedzy' - w konfrontacji z omówionym tu argumentem i z całą serią dalszych argumentów (których niewyczerpujący katalog został wyżej przedstawiony).

Zwróćmy się teraz ku własnemu potraktowaniu relacji 'wie, że' i 'jest przekonany, że' przez Ciecierskiego.

Przyjmuje on oczywiście implicatum 'wie, że' w postaci 'wie, czy', które z kolei implikuje 'bądź wie, że $p$, bądź wie, że $\sim p$ '. Nieoczekiwanie przywiązuje następnie do 'jest przekonany, że $p$ ' uznane przez siebie logiczne implicatum 'nie jest taki, że wie, że $\sim p$ ' (w niepoprawnej formie: nie wie, $\dot{z} e \sim p$; forma ta, wbrew zamiarom autora, ewidentnie implikuje prawdziwość $\sim p$ ). Jaki jest rezultat przedłożeń autora? Przypomnijmy, że jego głównym założeniem jest implikowanie przez 'wie, że' „nastawienia sądzeniowego" 'jest przekonany, że'. Po dołączeniu do tego założenia stypulacji 'nie jest taki, że wie, że $\sim p$ ' otrzymujemy poniższą implikację, której następnik opisuje 'wiedzącego, że $p$ ':

$a$ wie, że $p \Rightarrow[(a$ wie, że $p \vee a$ wie, że $\sim p) \wedge(a$ jest przekonany, że $p \Rightarrow a$ nie jest taki, że wie, że $\sim p$ ) $\wedge a$ jest przekonany, że $p$ ]

Alternatywa w pierwszym składniku następnika jest implicatum a wie, czy $p$ implikowanego przez $a$ wie, że $p$. Drugi składnik następnika jest stypulowany przez autora, jak o tym wspomniałem przed chwilą. Wprowadzenie tego składnika nie jest posunięciem trafnym, ponieważ można wiedzieć, że zachodzi/ zaszedł pewien stan rzeczy, a mimo to być w pewnym momencie przekonanym, że zachodzi kontradyktoryczny w stosunku do tamtego stan rzeczy (np. ktoś autentycznie wie, że nie włożył do teczki określonej książki, a potem szuka jej w teczce jako czegoś, czego obecności w niej jest w danym momencie pewien czy niemal pewien). Dla celów dyskusji przyjmijmy jednak ten składnik. Na mocy modus ponens składnik ten wraz z ostatnim składnikiem stanowi, że $a$ nie jest taki, że wie, że $\sim p$. Z kolei sylogizm dysjunkcyjny pozostawia $\mathrm{z}$ alternatywy $\mathrm{w}$ pierwszym składniku następnika jako ważny tylko jej pierwszy człon, tzn. $a$ wie, że $p$. W sumie w obrębie 
następnika dochodzi do ustalenia równoważności 'wie, że' $\equiv$ 'jest przekonany, że' (mamy tu też oczywiście równoważność tautologiczną 'wie, że $p$ ' $\Leftrightarrow$ 'wie, że $p$ ' oraz, rzecz jasna, implikację przekonania przez wiedzę).

Trudno o coś bardziej kontrintuicyjnego. Na dobrą sprawę zetknęliśmy się tutaj z niezamierzoną refutacja (na zasadzie reductio) logicznego implikowania 'przekonania' przez 'wiedzę', implikowania, na którym tak zależy autorowi. Autor oczywiście nie zadeklarowałby tezy, zgodnie z która 'przekonanie' implikuje 'wiedzę' (nalega on jedynie na to, że 'wiedza' implikuje 'przekonanie'). Ale jego drugi składnik wypisanego wyżej następnika 'wie, że' daje taki właśnie efekt, jaki tu opisałem, tzn. implikowanie wiedzy przez przekonanie.

Poza tymi komentarzami Ciecierskiego do stosunku 'wiedzy' i wyrażeń epistemicznych niealetycznych oraz różnych opinii na ten temat, komentarzami, które zostały wyżej omówione, autor odnosi się do pozycji w literaturze przedmiotu, w których chodzi bądź o trafne zgadywanie jakiegoś stanu rzeczy, bądź o sytuacje na tej czy innej zasadzie kłopotliwe z punktu widzenia podejmowanej atrybucji wiedzy i/lub przekonania. Uważa on te przypadki za bardziej frapujące i bardziej ciekawe filozoficznie niż te, o jakich mówiliśmy wyżej. Z taką globalną oceną trudno jest się zgodzić. Wprost przeciwnie, filozoficznie centralne są właśnie pytania, o których traktowaliśmy wyżej.

Zacznijmy od sytuacji zgadywania. Istotnie, po czyimś odgadnięciu czegoś mówimy często o „szczęśliwcu”, używając orzeczenia wie. Ale w takich przypadkach nikt nie mówi ani o wiedzy ani o przekonaniu na serio i literalnie. Ktoś, kto coś trafnie zgadł, może tylko powiedzieć m e t o $n$ i m i c zni e, że wiedział, zamiast powiedzieć, że wygłos ił coś, co $\boldsymbol{k}$ toś wie. Tego rodzaju okurencje mają całkiem oczywisty charakter równie wygodnych, co trywialnych zabiegów abrewiacyjnych (rzecz to ewidentnie należąca do pragmatyki).

Natomiast w wypadku autentycznej trudności określenia kogoś jako wiedzącego lub nie wiedzącego najczęściej mamy do czynienia z incydentalnymi kłopotami spowodowanymi na przykład brakiem należytego namysłu osób mających użyć tego lub innego określenia. Takie okoliczności nie mają żadnej wagi lingwistyczno-teoretycznej; co najwyżej mają one wagę dla opisu psychologicznego danego mówiącego/ danej grupy mówiących. 
Oczywiście istnieją szczególne sytuacje, w których dobór określenia może być autentycznie kontrowersyjny. Potwierdzają one jednak tylko elementarność i niedefiniowalność wyrażenia 'wie, że'. Rzecz w tym, że pojęcia elementarne ze względu na samą ich naturę mogą być dane tylko przez liczne, ale nie wszystkie, relewantne przykłady. Jest pewien graniczny przypadek pokazujący tę elementarność; mówiłem o nim w moim (2002). Chodzi o częste odezwania wiem, kto dzwoni (i inne podobne). Są one notorycznie fałszywe, a zarazem z punktu widzenia stanu mówiącego i jego odczucia owego stanu nie daja się zastapić żadnym innym wyrażeniem; nawet wyrażenie jestem stuprocentowo pewien, że to dzwoni Karol nie ma tej siły oddziaływania na odbiorcę, co owo odezwanie (w ogromnej liczbie przypadków, jakie mamy tu na widoku, identyfikacja osoby, o którą chodzi, okazuje się potem zbieżna z oczekiwaniami; w tym wypadku n i $\boldsymbol{e}$ mamy więc do czynienia z prawdziwie czystym zgadywaniem).

Omówiłem szczegółowe uwagi Ciecierskiego dotyczące konkretnych wyrażeń epistemicznych i ich ujęć proponowanych przez niektórych autorów. Wypada uzupełnić tę relację komentarzem do ogólnego obrazu tego, co autor nazywa „nastawieniami sądzeniowymi”, oraz do przeciwstawienia jego koncepcji przedłożeniom „niektórych lingwistów”, których wyróżnioną reprezentantką jest dla niego Danielewiczowa (praktycznie jedynie jako autorka jej (2002), mimo że ta książka należy do jej znacznie obszerniejszego dorobku). To przeciwstawienie jest niewątpliwie jedną z głównych osi jego wywodów.

Rozległe, w pewnym zakresie wyczerpujące, opracowanie Danielewiczowej uznaje Ciecierski za oparte na osobnej teorii, którą nazywa „naiwną teorią czasownikową". Ogólnie rzecz biorąc, sens wyrazu naiwny w odniesieniu do tych czy innych poglądów implikuje uznanie ich za prezentujące obraz rzeczywistości przynajmniej częściowo pod względem prawdziwościowym wypaczony, a wynikający zasadniczo z niedojrzałości i niekrytyczności lub niedostatecznej krytyczności myślenia właściwych wyznawcom tych poglądów. Taką ocenę opracowania Danielewiczowej przypieczętowuje Ciecierski, mówiąc wprost (s. 138): ,jest to zła koncepcja modalności psychologicznych” (określenie „modalności psychologiczne” jest tu ewidentnie nazwą alternatywną w stosunku do zasadniczego terminu autora, jakim są „,nastawienia sądzeniowe”).

Na czym, zdaniem autora, polega błędność owej „złej koncepcji”? Z jego omówienia można wyczytać dwie główne skazy: chodzi, po pierwsze, 
o oparcie analizy „nastawień sądzeniowych” na przyporządkowaniu ich konkretnym czasownikom i oglądzie szczegółów ich funkcjonowania, takich, jakie można obserwować $\mathrm{w}$ tekstach, pokładając zaufanie w jednolitości znaczeniowej odpowiednich okurencji w tych tekstach odpowiadającej realnym leksemom w ich całej indywidualności, po drugie, o zorientowanie całej analizy na wyróżniony jako pierwotny i niedefiniowalny czasownik wie, że $\mathrm{z}$ jego szczególną wyjściową charakterystyką składniową przewidującą jego rolę funktora $\mathrm{z}$ czterema argumentami. Ten ostatni punkt jest $\mathrm{w}$ opinii Ciecierskiego doniosły, ale również tak zasadniczo błędny, że całe przedmiotowe pole językowe oznacza on specjalnie ukutym terminem „,nastawienia sqdzeniowe” (z wariantem w postaci „modalności psychologicznych”). Za tym terminem kryje się myśl o potrzebie ustrzeżenia się Danielewiczowej terminu „wyrażenia epistemiczne”, który jego zdaniem wiąże się, niekorzystnie, z wykładnią obejmującą wskazaną fundamentalnie wadliwą tezą o niedefiniowalności 'wie, że'.

Co przeciwstawia Ciecierski skrytykowanej przez siebie koncepcji? Jego hasło zasadnicze zostało sfomułowane bardzo ogólnikowo w następujący sposób: do „nastawień sądzeniowych” („modalności psychologicznych”) należy zastosować ,pryzmat sieci związków analitycznych między zdaniami sądzeniowymi”. Do tego można dodać myśl autora, zgodnie z którą z dziedziną „nastawień sądzeniowych” kojarzą się wprawdzie znaczenia pewnych czasowników, ale jej elementy nie odpowiadają w prosty sposób czasownikom języków naturalnych (ani grupom ściśle synonimicznych czasowników w rodzaju sqdzić, mniemać [jeżeli taka synonimia istnieje]).

Jak ma wyglądać owa niezależna od tych czy innych czasowników „sieć związków analitycznych między zdaniami sądzeniowymi”? Autor jest tu lakoniczny. Rzecz sprowadza się w zasadzie do układu pojęciowego zaproponowanego na s. 136. Mamy tu następujące przecinające się parametry i przeciwstawienia w obrębie tych parametrów:

nastawienia proste vs. złożone

nastawienia wewnętrzne vs. zewnętrzne,

a ponadto, tylko w obrębie nastawień prostych (ale zarówno wewnętrznych, jak i zewnętrznych): 
nastawienia podstawowe vs. wtórne.

Charakterystyka tych kategorii w zasadzie ma wynikać z egzemplifikacji. Otrzymujemy mianowicie niżej podane przykłady:

proste wewnętrzne podstawowe: przekonanie

proste wewnętrzne wtórne: oczekiwanie

proste zewnętrzne podstawowe: rojenie sobie

proste zewnętrzne wtórne: brak egzemplifikacji (autor podaje znak ,???”)

złożone wewnętrzne: obawa

złożone zewnętrzne: żałowanie

Istotnym rysem tej taksonomii jest m.in. przeciwstawienie możliwej prawdziwości uzupełnienia propozycjonalnego i jego fałszu; tak jest w przypadku przekonania i rojenia sobie, w których zasadniczo „modalność psychologiczna" ma być ta sama (w rojeniu sobie chodzi po prostu o suponowany fałsz uzupełnienia propozycjonalnego). Trzeba też zwrócić uwagę na fakt, że w zgodzie z odrzuceniem wiązania ,nastawień sądzeniowych' z określonymi leksemami koncepcja Ciecierskiego pozwala na odwoływanie się w zaprojektowanych przez niego rubrykach zamiennie do bardzo różnych wyrażeń; tak na przykład w omówieniu różnicy między „nastawieniem wewnętrznym podstawowym” a ,zewnętrznym podstawowym” autor posługuje się zdaniami opartymi na czasowniku 'uważa', a nie 'jest przekonany' (w odniesieniu do pierwszej z tych kategorii, tzn. do „nastawienia wewnętrznego podstawowego"). Rzeczy różne są więc traktowane jako oboczne.

Jak należy ocenić streszczoną tu koncepcję?

Skoro autor zakwestionował obraz oparty na opisie indywidualnych wyrażeń z ich szczegółowymi osobliwościami semantycznymi, trzeba rozumieć, że w jego pojęciu „związki analityczne” między zdaniami są czymś innym niż przyjmowane gdzieś implikacje semantyczne wpisane w same czasowniki.

Nie można jednak wyobrazić sobie związków analitycznych między zdaniami, które nie miałyby choćby $\boldsymbol{j} \boldsymbol{a} \boldsymbol{k} \boldsymbol{i} \boldsymbol{e} \boldsymbol{g} \boldsymbol{o} \boldsymbol{s}$ odniesienia właśnie do czasowników, na jakich są zbudowane brane pod uwagę zdania.

Przyjmijmy to zastrzeżenie jako oczywiste. 
Wówczas bezpośrednio nasuwa się następująca możliwość interpretacji „modalności psychologicznych/ nastawień sądzeniowych” innej niż w drodze opisu poszczególnych czasowników. Można mianowicie myśleć o tych czy innych skończonych dysjunkcjach znaczeń zwykłych czasowników. Ciecierski nie wprowadza jednak ani jednej tego rodzaju dysjunkcji określonej przez wyliczenie; tu i ówdzie okazjonalnie i niezobowiązująco wspomina tylko o pewnych czasownikach jako ilustracjach swoich „modalności psychologicznych", przy czym ta ilustracyjność jest traktowana luźno. Należy stąd wnosić, że swe „modalności” koncypuje jako nie równe ani znaczeniom poszczególnych czasowników ani ich zamkniętym dysjunkcjom. (Dodajmy, że dysjunkcje jako dodatkowe pojęcia są w całej pełni możliwe, ale jedynie pod warunkiem, że składniki dysjunkcji przynajmniej w pewnym, choćby dalekim, miejscu odpowiednich rozwinięć nie stanowią już same dysjunkcji, lecz są proste; w przeciwnym wypadku grozi semantyczne niezamknięcie zdania, co oznacza, że w ogóle nic nie zostało powiedziane.)

Tymczasem całkowite oderwanie konstruowania pojęć od właściwości zastanego języka naturalnego jest niemożliwe, ponieważ tak czy inaczej proces ten polega na posługiwaniu się jego wyrażeniami. Już pierwsza z brzegu ostensja, bez której się nie można obyć, jeżeli się zaczyna mówić o czymkolwiek, jest dokonywana za pomocą środków języka zastanego, takich jak demonstrativum ten, ta, to. Tym bardziej jest tak tam, gdzie się mówi o mówieniu i o zjawiskach psychicznych skorelowanych z mówieniem.

Tym, co pozostaje, jeżeli ma się nie uwzględniać principiów, o których mówiliśmy, jest tworzenie pojęć aluzyjnych w postaci pewnych alternatyw z użyciem istniejących wyrazów lub neologizmów (typu sqdzeniowy) i z wykluczeniem sprecyzowanych wyliczeń członów alternatyw takich wyrazów, a następnie w postaci dalszych pojęć aluzyjnych o kształcie luźnych alternatyw poprzednio powstałych pojęć aluzyjnych. I taki status wypada przypisać prezentacji Ciecierskiego.

W efekcie otrzymujemy mówienie o mówieniu, które powinno być scharakteryzowane jako mówienie: ",", a nie jako mówienie, że _; i, dodajmy, mówienie inne niż takie mówienie cytacyjne, które realizuje poka z ywanie prawd apriorycznych (pokazywanie w sensie Traktatu Wittgensteina). Arystoteles określiłby to inne mówienie jako „mówienie dla samego mówienia” lub zbliżyłby je do ,poezji” przeciwstawionej przez niego wypowiedziom poważnym. Gdybyśmy mieli znaleźć jakąś paralelę w istniejącej literaturze 
z zakresu filozofii języka, można byłoby mówić o pewnym podobieństwie obrazu Ciecierskiego do preferowanej przez Merleau-Ponty „mowy wysławiającej”, w odróżnieniu od tego, co filozof francuski nazywa, z nastawieniem jawnie pejoratywnym, „mową wysłowioną".

Tymczasem elementarna, „wysłowiona”, baza języka jest apriorycznie tym, od czego się wszystko w życiu umysłowym zaczyna. Bezrefleksyjnie możemy mówić, posługując się znanymi sobie wyrażeniami, o faktach przygodnych. O Rzeczywistości natomiast jako przedmiocie filozoficznym, wraz z językiem (bo to są rzeczy wzajemnie nieodłączne), można na serio mówić tylko mówiąc jednocześnie, i równie na serio, o samym języku naturalnym - takim, jaki jest nam dany wcześniej. Bo Rzeczywistość nie jest obiektem empirycznym. Mogę sięgnąć ręka do szklanki, która stoi przede mną, p o n a d czy też p o z a zastanym językiem (z jego słowem szklanka). Jedynym sposobem sięgnięcia do Rzeczywistości (zawsze uobecniającej się wraz z językiem!) jest mówienie. A mówienie o niej p o n a d zastanym językiem (bez badania właśnie jego, języka) to zaledwie arbitralne, literackie tworzenie odgałęzień i przybudówek języka w jego literalnym rdzeniu. Trawestując de Saussure'a, trzeba powiedzieć: jeżeli poszukujemy prawdy o Rzeczywistości, musimy pamiętać, że w tej mierze la langue seule ne se trompe pas.

Podsumujmy tę dyskusję. Sprawą fundamentalną jest fakt, iż 'wie, że' odnosi się niemetaforycznie na równi do organizmów mówiących i niemówiących, natomiast pojęcia czy wyrażenia 'jest przekonany, że', 'sądzi, że' etc. przesądzają obecność zdolności mownej podmiotu (por. dewiacyjne, przy założeniu literalności, *pies pomyślat, że etc.). W organizmach mówiqcych wiedza sąsiaduje z przekonaniami, wyobrażeniami itd. Stąd najpewniej pochodzi tak rozpowszechniona skłonność do dyfuzyjnego traktowania tych zasadniczo różnych wielkości. Tymczasem w organizmach niemówiących t a s a ma wie d za - występuje s ol o (czymś zupełnie innym jest sprawa tego, jakie są treści wiedzy istot niemówiących, z jednej strony, a istot mówiących, z drugiej strony).

O tych sprawach Ciecierski nie mówi. W odniesieniu do nich znajdujemy u niego jedynie nieobowiązujące wzmianki o, ,przekonaniach" zwierzat. Warto w tym związku powiedzieć, że samo wyrażenie przekonania zwierząt może być co najwyżej arbitralnym konstruktem werbalnym o niewiadomej 
denotacji. Zwraca także uwagę fakt, że w pewnych nie całkiem jasnych sformułowaniach autor dopuszcza zupełny brak stanów zasługujących na miano wiedzy, co przywodzi na pamięć błędne poglądy radykalno-sceptyczne w stylu Ungera (1975) (dodajmy, że od tych swoich wcześniejszych poglądów filozof brytyjski później się dystansował - na rzecz tzw. „kontekstualizmu”).

\section{Bibliografia}

Abelson R., 1968, Knowledge and belief, Journal of Philosophy 65 (22), s. 725-732.

BogusŁaWski A., 1981, Wissen, Wahrheit, Glauben: zur semantischen Beschaffenheit des kognitiven Vokabulars, in: Th. Bungarten (ed.), Wissenschaftssprache. Beiträge zur Methodologie, theoretischen Fundierung und Deskription, München: Fink, s. 54-84.

BogusŁawski A., 1986, Also from all so. On a set of particles in service of efficient communication, Journal of Pragmatics 10, s. 615-633.

BogusŁawski A., 1988, Jezzyk w stowniku. Desiderata semantyczne do wielkiego stownika polszczyzny, Wrocław: Ossolineum.

BogusŁawski A., 1991, This, w: M. Grochowski (ed.), Problemy opisu gramatycznego języków stowiańskich, Warszawa: Wydawnictwo SGGW, s. 23-30.

BogusŁawski A., 1994, Czy wiedza, że $p$, pociąga za sobą inny stan mentalny?, w: J. Pelc (red.), Znaczenie i prawda, Warszawa: Wydawnictwo Naukowe PWN, s. $391-412$.

BogusŁawski A., 1998, Science as Linguistic Activity, Linguistics as Scientific Activity, Warszawa: Katedra Lingwistyki Formalnej Uniwersytetu Warszawskiego.

BogusŁawski A., 2002, There is no getting round Gettier, Journal of Pragmatics 34, s. 921-937.

Bogustawski A., 2005, On Danielewiczowa's panorama of epistemic verbs. A gloss with draft amendments, Lingua Posnaniensis XLVII, s. 21-38.

BogusŁawski A., 2005a, Przypomnienia metodologiczne. Uzupełnienia, Biuletyn Polskiego Towarzystwa Językoznawczego LXI, s. 89-96.

Bogustawski A., 2007, A Study in the Linguistics-Philosophy Interface, Warszawa: BEL Studio.

BogusŁawski A., 2007a, Wiedza, fałsz, prawda: słowo o ich relacji wzajemnej, Przeglad Humanistyczny LI, 1, s. 1-7.

Ciecierski T., 2013, Nastawienia sqdzeniowe. Wykłady z filozofii psychologii, Warszawa: Wydawnictwo Naukowe PWN.

Danielewiczowa M., 2002, Wiedza i niewiedza. Studium polskich czasowników epistemicznych, Warszawa: Katedra Lingwistyki Formalnej UW. 
Geach P., 1963, Assertion, The Philosophical Review 74, 4, s. 449-465.

Gettier E.L., 1963, Is justified true belief knowledge?, Analysis 23, s. 121-123.

Unger P., 1975, Ignorance. A Case for Scepticism, Oxford: Clarendon.

Woleński J., 2005, Epistemologia. Poznanie, prawda, wiedza, realizm, Warszawa:

Wydawnictwo Naukowe PWN.

\section{One more gloss to the debate over the concept of knowledge and its relationship to non-aletheic mental states}

( s u m m a r y)

The author recalls the controversy over the definability or indefinability of the concept of knowledge, more exactly, of the concept 'knows that', and presents a catalogue of arguments in favour of its indefinability.

The main part of the article is a critical discussion of T. Ciecierski's (2013) view of what he calls ,nastawienia sądzeniowe” (roughly, ,belief attitudes”) as being based on what he is prepared to dub an ,elementary” truth, viz. the would-be truth of the claim that 'know that' is doxastically definable. 